duce from nearby farms, fresh seafood, locally made jam and cheese, and many other tasty treats from the Puget Sound area. The farmers' market bounty also appears in several restaurants near the market. The Pike Brewing Company (1415 First Ave., pikebrewing.com) features a pub menu with local produce, fish, meats, and handcrafted beer. One of Seattle's Produce at Pike Place Market. Photo credit: most famous chefs, Tom Justin D. Henry. Douglas, showcases the region's seafood at Etta's (2020 Western Ave., tomdouglas. com/ettas). Chez Shea (top floor, Corner Market building, 94 Pike St., chezshea.com) offers a French approach to market-fresh ingredients, and Steelhead Diner (95 Pine St.,

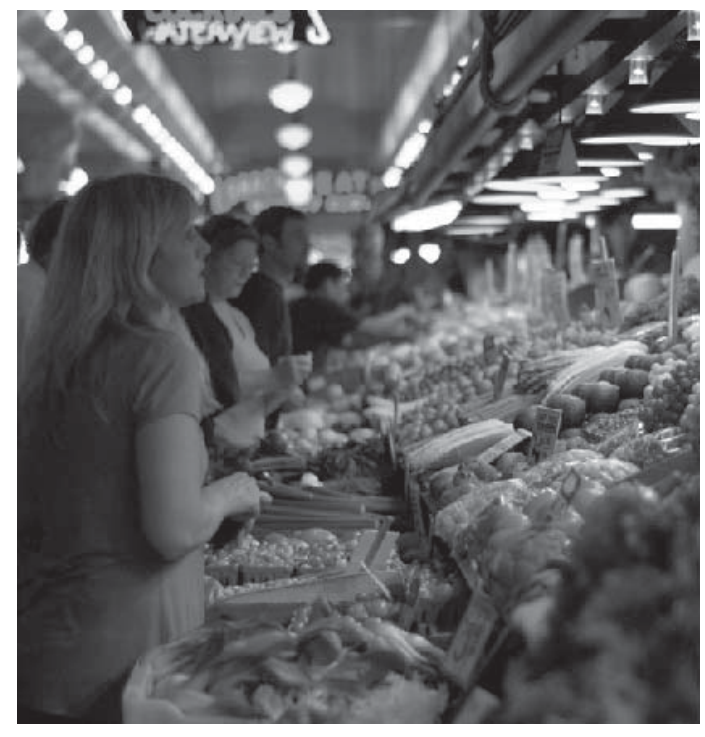

steelheaddiner.com) serves diner-inspired Pacific Northwest haute cuisine.

Many other downtown restaurants offer local, seasonal food. Just steps from the convention center is Organic To Go (601 Union St., Suite 224A, organictogo.com, open Monday-Friday, 6:30 a.m.-4 p.m.), which has an entirely organic and partially local menu. Brasa (2107 3rd Ave., brasa.com) serves up a Mediterranean take on Northwest ingredients. In the Elliott Bay Bookstore, Elliott Bay Cafe (101 South Main St., elliottbaybook.com/about/cafe), features a local-focus menu recently revised by $\mathrm{Ta}-$ mara Murphy, the chef at Brasa. Union Square

\title{
Six steps to greening your ACRL 14th National Conference experience
}

The Green Conference Planning Committee for the ACRL National Conference has been working hard to build environmentally sustainable practices into this year's conference in Seattle. Here are six ways to make this your greenest ACRL ever.

1. Take the pledge. Earlier this year the Green Committee surveyedACRL members to find out what mattered most in greening our conference. We used the results to draft the Green Pledge.

The pledge asks all conference participants to make sustainability a priority throughout the conference. Participants who take the pledge agree to learn, inform, think, and act sustainably in the months leading up to and during the conference.

Some suggested pledge activities are walking or using public transportation, accessing handouts through ACRL's virtual conference space, recycling paper handouts (or not using them in the first place), consulting the ACRL interactive conference map for local and green restaurants and businesses, and using the conference program to learn which vendors provide sustainable services and practices. You can review the Green Pledge at tinyurl.com/ greenpledge.

The committee urges everyone to accept the Green Pledge when registering for the conference.Your participation in the Green Pledge effort will be reflected by a green leaf on your registration badge.

2. Get green giveaways. All conference participants will receive green giveaways this year:a bag made of 51 percent recycled fabric and matching badge holder, and a corn plastic, BPA-free mug.

You can make your giveaways even greener by recycling your badge holder before you leave the convention center-look for the drop box in the registration area.

You'll also have the opportunity to enter a drawing to win one free registration for the 2011 ACRL conference in Philadelphia. If you miss us there, you can enter the drawing at the Green Speaker program, as well. 
Grill (621 Union St., unionsquaregrill.com) and the restaurant at the Seattle Art Museum, TASTE (1300 1st Ave., tastesam.com), both rely heavily on Puget Sound-area ingredients for their "New American" meals. Farestart (700 Virginia St., farestart.com, open Monday-Friday, 11 a.m.-2 p.m. and Thursdays 6-8 p.m.), a nonprofit that provides culinary training for students from disadvantaged backgrounds, puts local, seasonal food on the lunch table during the work week, and brings in premier local chefs for often sold out "Guest Chef Nights" on Thursday evenings.

\section{Pacific Northwest cuisine elsewhere in Seattle}

Those willing to venture beyond the urban core will find many options for sampling $\mathrm{Pa}-$ cific Northwest cuisine in Seattle's neighborhoods. Seattle's public transportation system is not as robust as it will be soon, with a light rail system scheduled to debut sometime in 2009, but most of these restaurants are a bus or taxi ride from downtown. Cabs can be hailed from most downtown hotels or requested by calling the local cab service (206-622-6500). Bus trips can be planned using Metro's online Trip Planner (tripplanner. metrokc.gov) and by using other online tools (transit.google.com, busmonster.com, mybus. org, or onebusaway.org).

Popular neighborhood restaurants that seek out the bounty of nearby farms and artisans include Pair (5501 30th Ave. NE, pairseattle.com), Lark (926 12th Ave, larkseattle.com), Stumbling Goat Bistro (6722 Greenwood Ave. N, stumblinggoatbistro. com), and Volunteer Park Café (1501 17th Ave. E, alwaysfreshgoodness.com). "Sicilian soul food" made with local ingredients is the specialty at La Medusa (4857 Rainier Ave. S, lamedusarestaurant.com) in the Columbia City neighborhood. Succulent steak frites and other European dishes can be found at Fremont's 35th Street Bistro (709 N. 35th St., 35bistro.com). Also in Fremont is Tilth (1411
3. Hear a great green speaker. The committee is delighted to present a featured Green Speaker. Robin Chase is cofounder and former CEO of Zipcar, the largest car-sharing company in the world. She is currently CEO of GoLoco, an innovative online ridesharing community. Chase has revolutionized the way people travel by combining transportation with social networking.Attend Chase's session from 8 a.m. to 9 a.m Sunday, March 15.

4. Learn bow to green your own conference. For those interested in learning more about what it takes to green a conference, the Green Committee will offer a panel session from 10:30 to 11:30 a.m. on Saturday, March 14.We'll talk about drafting the green survey and the corresponding pledge, strategies for greening a convention center, how to investigate green hotel practices, lessons learned along the way, and more.

5.Visit the Green Committee. Don't forget to look for the Green Committee's table in the convention center's registration area.
We'll answer your questions about "behindthe-scenes" greening efforts (recycled pipe and drape, anyone?) and help you enter to win some great prizes. We'll also have a recycling station for your paper handouts. If you haven't already done so, you can take the Green Pledge there, and we'll give you a sticker for your badge.

6. Help spread the green. Because this will be ACRL's first green conference, there's a lot of excitement about coming together to lessen our environmental impact in Seattle. There are already plans underway to carry this initiative forward into the future of ACRL conference planning. The Green Committee is looking to all of ACRL membership to help make our first green conference a success!-Juliet Kerico is science and bealth sciences librarian at Southern Illinois University-Edwardsville, jkerico@siue.edu, and Karen Munro is bead of the UO Portland Library and Learning Commons at the University of Oregon,kmunro@uoregon.edu 